\title{
Plasma levels and expression of vascular endothelial growth factor-A in human localized prostate cancer
}

\author{
MICHAËL PEYROMAURE ${ }^{1}$, CÉCILE BADOUAL $^{7}$, PHILIPPE CAMPARO $^{8}$, SOPHIE GRABAR $^{2}$, \\ CLAIRE GOULVESTRE ${ }^{3}$, YVONNE FULLA ${ }^{4}$, ANNICK VIEILLEFOND ${ }^{5}$, \\ KAILI MAO ${ }^{1}$ and ANH-TUAN DINH-XUAN ${ }^{6}$
}

\begin{abstract}
Departments of ${ }^{1}$ Urology, ${ }^{2}$ Biostatistics, ${ }^{3}$ Biological Immunology, ${ }^{4}$ Nuclear Medicine, ${ }^{5}$ Pathology, ${ }^{6}$ Physiology, Cochin Hospital; ${ }^{7}$ Department of Pathology, European-Georges Pompidou Hospital;

${ }^{8}$ Department of Pathology, Val de Grâce Hospital, 75014 Paris, France
\end{abstract}

Received March 11, 2007; Accepted April 23, 2007

\begin{abstract}
Although the impact of vascular endothelial growth factor (VEGF) is clearly established in advanced prostate cancer $(\mathrm{PCa})$, its role in localized $\mathrm{PCa}$ remains to be determined. The aim of our study was to analyse the plasma levels of VEGF-A and the expression of VEGF-A in prostatic tissue in a population of patients with localized $\mathrm{PCa}$. We measured the preoperative plasma levels of VEGF-A in 100 patients undergoing radical prostatectomy (RP) for clinically-localized PCa. After intervention, we determined the expression of VEGF-A in all RP specimens using immunohistochemistry. We found no association between plasma levels of VEGF-A and the established prognostic factors of PCa. Moreover, there was no association between plasma levels of VEGF-A and the expression of VEGF-A in prostatic tissue. On the contrary, there was a strong correlation between the expression of VEGF-A in PCa tissue and the Gleason score of cancer: the expression of VEGF-A was significantly higher in patients with a high Gleason score on RP specimen $(p=0.01)$. Our results suggest that the expression of VEGF may have a prognostic impact in clinically-localized PCa.
\end{abstract}

\section{Introduction}

Vascular endothelial growth factor (VEGF) is a glycoprotein acting as a specific endothelial mitogen. The VEGF gene family encodes five polypeptide growth factors: VEGF-A, -B, $-\mathrm{C},-\mathrm{D}$ and $-\mathrm{E}$ (1). VEGF-A can induce vascularization around growing tumor cells, and is overexpressed in prostatic tumors

Correspondence to: Dr Michaël Peyromaure, Service d'Urologie, Hôpital Cochin, 27 rue du Faubourg Saint-Jacques, 75014 Paris, France

E-mail: michael.peyromaure@cch.aphp.fr

Key words: prostate cancer, angiogenesis, vascular endothelial growth factor such as benign prostatic hyperplasia and prostate cancer (PCa) (2). It has been suggested that VEGF expression may be regulated by some tumor suppressor genes, including the PTEN (phosphatase, tensin homologue) gene on chromosome $10 q 23$ (3). Several investigators found a correlation between circulating levels of VEGF-A and the aggressiveness of PCa, but others reached opposite conclusions (4-6). Moreover, most published studies have analysed the impact of VEGF-A in advanced PCa. The impact of VEGF-A in localized PCa remains therefore to be determined.

In the current study we measured the preoperative plasma levels of VEGF-A in 100 consecutive patients undergoing RP for localized PCa. We also examined the VEGF-A expression in the RP specimens, and analysed the associations between pre-RP VEGF plasma levels, VEGF expression in PCa tissue and established prognostic factors of $\mathrm{PCa}$.

\section{Materials and methods}

Patient selection. One hundred consecutive patients undergoing RP for clinically-localized PCa at our institution were prospectively enrolled between June and November 2005. None had received hormone therapy, radiation therapy or chemotherapy before intervention. All patients had undergone pelvic CT scan, endorectal magnetic resonance imaging (MRI) and bone scintigraphy before RP. None had clinical or radiological evidence of lymph node or bone metastases. A bilateral pelvic lymphadenectomy was performed at the time of RP. Clinical and pathological stages of PCa were established according to the 2002 TNM classification.

Assessment of biomarkers (serum PSA and VEGF). Blood was taken from all patients the day before RP and was collected into two 7-ml glass tubes. One tube was used to measure the different forms of PSA. Total PSA, free PSA and complexed PSA were measured in serum using the Bayer Immuno 1 PSA assay. The other tube was used to measure plasma levels of VEGF-A. VEGF-A was measured using an enzymelinked immunosorbent assay (ELISA). Blood was spun at $2500 \mathrm{~g}$ for $10 \mathrm{~min}$; then, the platelet-poor plasma was removed and placed in a $5-\mathrm{ml}$ tube, stored at $-80^{\circ} \mathrm{C}$ and thawed 
immediately before testing. VEGF-A levels were determined in duplicate with $100 \mu \mathrm{l}$ of each sample. According to their amino acid content, 5 isoforms of VEGF-A have been identified, namely VEGF 121, VEGF 145, VEGF 165, VEGF 189 and VEGF 206. The immunoassay that we used (Bender MedSystems, Vienna, Austria) is designed to measure all these isoforms.

Tissue microarrays. Slides from the 100 RP specimens were reviewed and mapped. Tissue microarrays were built using a manual tissue arrayer (Beecher Instruments, Alphelys). Areas representative of the tumor with the highest Gleason score were circled. Duplicate $0.6 \mathrm{~mm}$ cores were obtained from the circled areas of tumor and transferred to a recipient paraffin block. Controls were obtained from non-malignant prostatic tissue. The tissue array set consisted of 8 blocks, and included the coordinates of each core and case of origin.

Immunohistochemistry. Immunochemical staining was performed on the section mounted on poly-L-Lysine coated glass slides. Before incubation with primary antibodies, deparaffinized and rehydrated sections were incubated with avidin/ biotin blocker (Vector Laboratories, Burlingame, USA) and Fc receptor blocked by human serum (5\%). Antigen retrieval was accomplished by heating the slides at $97^{\circ} \mathrm{C}$ in a $0.01-\mathrm{M}$ citrate buffer ( $\mathrm{pH}$ 6.0) for $15 \mathrm{~min}$. An anti-VEGF A-20 Mab (clone sc-152; Santa Cruz Biotechnology, CA, USA) was used at the dilution of 1:200 for $1 \mathrm{~h}$. After rinsing in PBS, the biotinylated secondary antibody was applied for $30 \mathrm{~min}$. To visualize the reaction, sections were incubated with an AEC substrate chromogen (Dakocytomation, Copenhagen, Denmark) for 15 to $20 \mathrm{~min}$ at room temperature. Slides were mounted with Glycergel (Dakocytomation) mounting medium and evaluated under a conventional light microscope. Breast carcinoma tissues were used as positive controls.

Evaluation of immunostaining. A semi-quantitative scoring system was used for the evaluation of immunostaining. Two pathologists (CB, PC) blinded to clinical data independently scored the slides. The intensity of staining was scored as 0 , no detectable signal; 1 , weak staining; 2 , moderate staining; and 3 , strong staining. The percentage of positive cells was scored as 0 , no positive cells; $1,<1 / 3$ positive cells; $2,1 / 3$ $2 / 3$ positive cells; and $3,>2 / 3$ positive cells. Because of the duplicate nature of the arrays, two values were obtained for each patient. The highest intensity value was considered for analysis. The sum index was obtained by totaling the score of intensity and the percentage of positive cells. VEGF expression was defined as low (sum index $\leq 3$ ) or high (sum index $>3$ ).

Statistical analysis. Statistical analysis was performed using the Statistical Analysis System, version 8.2 (SAS Institute Inc., Cary, NC, USA). Quantitative data were expressed in median values and interquartile range (IQR). The Kruskal Wallis and the Wilcoxon tests were used to test for differences in plasma VEGF-A and PSA levels between preoperative (clinical stage, pathological stage, Gleason score and surgical margins status), postoperative features (Gleason score, pathological stage and surgical margin status) and VEGF-A

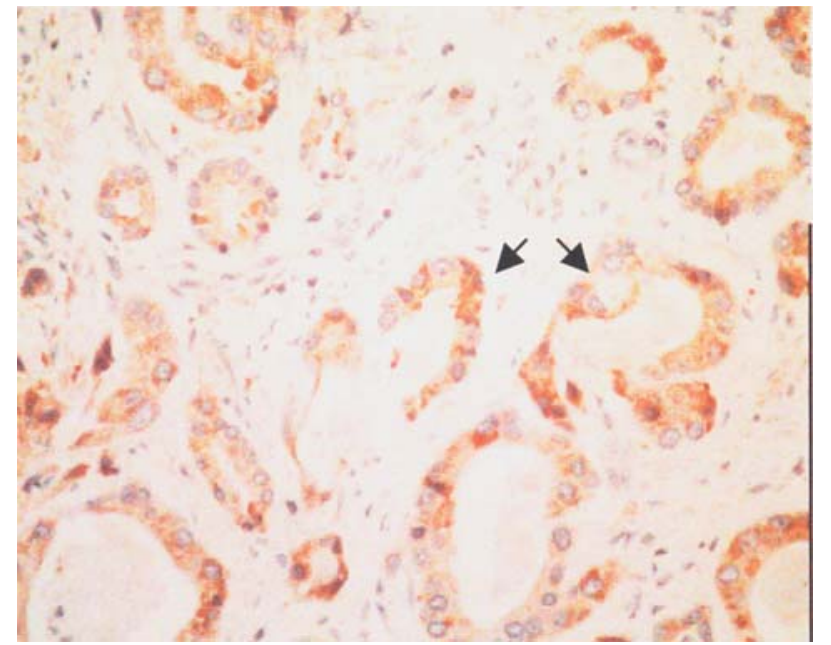

Figure 1. Case of PCa with high VEGF-A expression (intensity score 3) $\mathrm{x} 400$.

expression (low or high) in PCa tissue. The Spearman correlation coefficient was used to study the associations between quantitative variables. Associations between VEGFA expression in PCa tissue and qualitative variables (clinical stage, pathological stage, Gleason score and surgical margins status) were determined using the Fisher's exact test. The Fisher's exact test was used to study the associations between preoperative Gleason score, PSA, MRI findings, postoperative Gleason score, pathological stage and surgical margin status.

\section{Results}

The median plasma level of VEGF-A was $145.5 \mathrm{pg} / \mathrm{ml}$ (IQR 55.5-230; range 0-4,100). VEGF-A expression in PCa tissue could be determined in 89 cases. VEGF-A expression in $\mathrm{PCa}$ tissue was low in 53 patients, and high in the remaining 36. In patients with a positive staining, VEGF-A was detectable in stromal and in epithelial cells (Fig. 1).

There was no association between plasma VEGF-A values and patient age $(\mathrm{p}=0.22)$, prostate weight $(\mathrm{p}=0.46)$, total PSA $(\mathrm{p}=0.48)$, free/total PSA $(\mathrm{p}=0.9)$ or complexed PSA $(\mathrm{p}=0.51)$. Moreover, there was no association between VEGF-A expression in $\mathrm{PCa}$ tissue and patient age, prostate weight, different forms of PSA, or plasma VEGF-A (Table I).

Table II shows the plasma levels of VEGF-A according to preoperative and postoperative prognostic factors of $\mathrm{PCa}$. There was no association between the plasma levels of VEGF-A and preoperative tumor characteristics. The plasma levels of VEGF-A were lower in patients with a high Gleason score on RP specimen $(\mathrm{p}=0.04)$. However, there was no association between the plasma levels of VEGF-A and pathological stage of PCa $(\mathrm{p}=0.57)$ or surgical margin status $(\mathrm{p}=0.48)$.

Table III shows the expression of VEGF-A in PCa tissue according to preoperative and postoperative tumor characteristics. There was no association between the expression of VEGF-A in PCa tissue and preoperative tumor characteristics. The expression of VEGF-A in PCa tissue was significantly higher in patients with a high Gleason score on RP specimen $(\mathrm{p}=0.01)$. 
Table I. Association between VEGF-A expression in cancer tissue and quantitative parameters.

\begin{tabular}{|c|c|c|c|}
\hline & $\begin{array}{c}\text { Low VEGF-A } \\
\text { expression }\end{array}$ & $\begin{array}{l}\text { High VEGF-A } \\
\text { expression }\end{array}$ & P-value ${ }^{b}$ \\
\hline $\begin{array}{l}\text { Age median/ } \\
\text { IQR }^{\mathrm{a}} \text { (years) }\end{array}$ & $62 / 57-66$ & 63/59-68 & 0.42 \\
\hline $\begin{array}{l}\text { Prostate weight } \\
\text { median/IQR }{ }^{\mathrm{a}} \\
(\mathrm{gr})\end{array}$ & $44 / 38-54$ & $46 / 33.5-56.5$ & 0.42 \\
\hline $\begin{array}{l}\text { Total PSA } \\
\text { median/IQR }{ }^{\mathrm{a}} \\
(\mathrm{ng} / \mathrm{ml})\end{array}$ & $5.5 / 3.7-7.6$ & $5.6 / 4-10.9$ & 0.28 \\
\hline $\begin{array}{l}\text { Free/total PSA } \\
\text { median/IQR } \\
(\%)\end{array}$ & $14 / 11-19$ & 11.5/8.5-19 & 0.19 \\
\hline $\begin{array}{l}\text { Complexed PSA } \\
\text { median/IQR } \\
(\mathrm{ng} / \mathrm{ml})\end{array}$ & $4.8 / 3.2-7$ & $4.8 / 3.7-10.3$ & 0.29 \\
\hline $\begin{array}{l}\text { Plasma VEGF } \\
\text { median/IQR }{ }^{\mathrm{a}} \\
(\mathrm{pg} / \mathrm{ml})\end{array}$ & $151 / 57-273$ & $139 / 61-218$ & 0.70 \\
\hline
\end{tabular}

${ }^{\mathrm{a}}$ Interquartile range. ${ }^{\mathrm{b}}$ Wilcoxon test.

Two factors were found to be associated with the pathological stage of PCa: the free/total PSA ratio and the post-operative Gleason score. The median free/total PSA ratio was $14 \%$ in patients with a pT2 tumor versus $11.5 \%$ in those with a pT3 tumor $(\mathrm{p}=0.04)$. The rates of extracapsular disease were $19.2,50,56.3$ and $83.3 \%$ in patients with a Gleason score $\leq 6$ or of $3+4,4+3$ and $>7$, respectively $(p=0.002)$. Finally, the sole factor associated with surgical margin status was the pathological stage of PCa. Of the patients with positive surgical margins, $26.3 \%$ had a pT2 tumor and $73.7 \%$ had a pT3 tumor $(\mathrm{p}=0.001)$.

\section{Discussion}

The clinical impact of VEGF in metastatic PCa has been documented by several studies. Duque et al compared the plasma levels of VEGF-A in 54 patients with localized PCa, 26 patients with metastatic PCa, and 26 controls (4). They found a significant increase in VEGF-A in patients with metastases compared with patients with localized disease and controls. The role of VEGF in metastatic PCa was also suggested by George et al, who found in a series of 197 patients with hormone-refractory $\mathrm{PCa}$ that the plasma levels of VEGF-A were independently associated with overall survival (7). The evidence that VEGF plays a significant role in advanced PCa has led to the development of anti-angiogenic therapies. These targeted therapies include bevacizumab, a humanized VEGF-specific monoclonal antibody (8). Anti-
Table II. Plasma levels of VEGF-A according to preoperative and postoperative tumor characteristics.

\begin{tabular}{lcc}
$\begin{array}{l}\text { Tumor } \\
\text { characteristics }\end{array}$ & N $(\%)$ & $\begin{array}{c}\text { VEGF-A median } \\
\mathrm{IQR}^{\mathrm{a}}(\mathrm{pg} / \mathrm{ml})\end{array}$ \\
\hline $\begin{array}{l}\text { Gleason score on biopsy } \\
\leq 6\end{array}$ & $59(59)$ & $182 / 75-232$ \\
$3+4$ & $24(24)$ & $80.5 / 5.5-218$ \\
$4+3$ & $11(11)$ & $71 / 28-110$ \\
$>7$ & $6(6)$ & $64 / 58-208$ \\
P-value & & 0.13 \\
Clinical stage of PCa & & \\
T1c & $71(71)$ & $163 / 36-250$ \\
T2a & $23(23)$ & $89 / 57-159$ \\
T2b & $6(6)$ & $460 / 0-511$ \\
P-value & & 0.11
\end{tabular}

Percentage of positive

biopsy cores

$\begin{array}{lcc}<25 & 34(34) & 152 / 34-233 \\ 25-49 & 34(34) & 137.5 / 36-215 \\ 50-74 & 25(25) & 134 / 63-250 \\ \geq 75 & 7(7) & 182 / 0-192 \\ \text { P-value } & & 0.96\end{array}$

Endorectal MRI findings

No extracapsular $\quad 88(88)$

$139 / 55.5-230.5$

extension

Suspected extracapsular

$7(7)$

$163 / 58-437$

extension

Extracapsular extension

$5(5)$

$154 / 0-208$

0.75

Gleason score on RP specimen

$\leq 6$

$52(52)$

$189 / 89-233$

$3+4$

24 (24)

139/45.5-373

$4+3$

$>7$

16 (16)

$62.5 / 19.5-123$

$6 \quad(6)$

112.5/3-159

0.04

Pathological stage of PCa

pT0

pT2a

pT2b

pT2c

22 (22)

264.5/224-486

pT3a

$139 / 58-328$

34 (34)

$125 / 57-214$

pT3b

34 (34)

$152.5 / 54-215$

$\mathrm{P}-$ value $^{\mathrm{b}}$

2 (2)

218.5/0-437

0.57

Surgical margin status

$\begin{array}{lcc}\text { Positive } & 19(19) & 135 / 3-224 \\ \text { Negative } & 81(81) & 154 / 58-232 \\ \text { P-value }^{b} & & 0.48\end{array}$

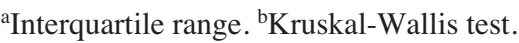

angiogenic agents are still under investigation in clinical trials, but in vivo studies have reached promising conclusions (9). 
Table III. Expression of VEGF-A in PCa tissue according to preoperative and postoperative tumor characteristics.

\begin{tabular}{|c|c|c|}
\hline $\begin{array}{l}\text { Tumor } \\
\text { characteristics }\end{array}$ & $\begin{array}{c}\text { Low VEGF-A } \\
\text { expression } \\
\mathrm{N}(\%)\end{array}$ & $\begin{array}{c}\text { High VEGF-A } \\
\text { expression } \\
\mathrm{N}(\%)\end{array}$ \\
\hline \multicolumn{3}{|l|}{ Gleason score on biopsy } \\
\hline$\leq 6$ & $36(67.9)$ & $16(44.4)$ \\
\hline $3+4$ & $10(18.9)$ & $11(30.5)$ \\
\hline $4+3$ & $4(7.5)$ & $6(16.7)$ \\
\hline$>7$ & $3(5.7)$ & $3(8.4)$ \\
\hline P-value ${ }^{a}$ & & 0.87 \\
\hline \multicolumn{3}{|l|}{ Clinical stage of $\mathrm{PCa}$} \\
\hline $\mathrm{T} 1 \mathrm{c}$ & $40(75.4)$ & $23(63.9)$ \\
\hline $\mathrm{T} 2 \mathrm{a}$ & $10(18.9)$ & $10(27.8)$ \\
\hline $\mathrm{T} 2 \mathrm{~b}$ & $3(5.7)$ & $3(8.3)$ \\
\hline P-value ${ }^{a}$ & & 0.47 \\
\hline \multicolumn{3}{|l|}{$\begin{array}{l}\text { Percentage of positive } \\
\text { biopsy cores }\end{array}$} \\
\hline$<25$ & $17(32.2)$ & $10(27.8)$ \\
\hline $25-49$ & $19(35.8)$ & $11(30.6)$ \\
\hline $50-74$ & $13(24.5)$ & $12(33.3)$ \\
\hline$\geq 75$ & $4 \quad(7.5)$ & $3(8.3)$ \\
\hline P-value ${ }^{a}$ & & 0.84 \\
\hline \multicolumn{3}{|l|}{ Endorectal MRI findings } \\
\hline No extracapsular extension & $48(90.6)$ & $29(80.6)$ \\
\hline $\begin{array}{l}\text { Suspected extracapsular } \\
\text { extension }\end{array}$ & $5 \quad(9.4)$ & $7(19.4)$ \\
\hline P-value ${ }^{a}$ & & 0.21 \\
\hline \multicolumn{3}{|l|}{$\begin{array}{l}\text { Gleason score on RP } \\
\text { specimen }\end{array}$} \\
\hline$\leq 6$ & $34(64.2)$ & $12(33.3)$ \\
\hline $3+4$ & $12(22.6)$ & $12(33.3)$ \\
\hline $4+3$ & $7(13.2)$ & $7(19.5)$ \\
\hline$>7$ & & $5(13.9)$ \\
\hline P-value ${ }^{a}$ & & 0.01 \\
\hline \multicolumn{3}{|l|}{ Pathological stage of $\mathrm{PCa}$} \\
\hline $\mathrm{pT} 2 \mathrm{a}$ & $3(5.7)$ & $1 \quad(2.8)$ \\
\hline pT2b & $12(22.6)$ & $7(19.4)$ \\
\hline pT2c & $22(41.5)$ & $12(33.3)$ \\
\hline pT3a & $15(28.3)$ & $15(41.7)$ \\
\hline pT3b & 1 (1.9) & $1 \quad(2.8)$ \\
\hline P-value ${ }^{a}$ & & 0.38 \\
\hline \multicolumn{3}{|l|}{ Surgical margin status } \\
\hline Positive & $10(18.9)$ & $7(19.4)$ \\
\hline Negative & $43(81.1)$ & $29(80.6)$ \\
\hline P-value ${ }^{a}$ & & 1 \\
\hline
\end{tabular}

aFisher's exact test.

Although VEGF plays an important role in metastatic $\mathrm{PCa}$, its impact in localized disease remains to be clarified. Our team has previously analysed the diagnostic value of
VEGF for the early detection of PCa (10). We measured VEGF-A in 47 patients who underwent prostate biopsies on clinical and/or biological suspicion of $\mathrm{PCa}$, and found that VEGF was not predictive of cancer on biopsies. This study relied on serum samples. Because VEGF measured in serum may be released from platelets on activation after venipuncture (11), we decided, in the current study, to measure VEGF in plasma.

Shariat et al analysed the plama levels of VEGF-A in 215 patients who underwent RP for clinically-localized $\mathrm{PCa}$, in 9 patients with untreated metastatic $\mathrm{PCa}$, and in 40 controls (5). In this study, preoperative levels of VEGF-A were significantly elevated in patients with Gleason score $\geq 7$, in patients with extraprostatic stage, and in those with lymph node involvement. Moreover, patients with plasma levels of VEGF-A above the median had an increased risk of biochemical progression after RP. The authors concluded that preoperative levels of VEGF-A could help to predict the tumoral stage and the clinical outcome of patients. The results of our current study gave rise to different conclusions. Such discrepancy may be due to differing methods of VEGF measurement: we used a polyclonal antibody that is designed to measure all the isoforms of VEGF-A, whereas Shariat et al used an immunoassay technique that measures only two isoforms of VEGF-A (VEGF 121 and VEGF 165) (5).

A surprising finding in our study is that VEGF-A levels were lower in patients with a high Gleason score. However, this result should be considered with caution, owing to the small sample of patients with a high Gleason score. In fact, the vast majority of patients had a Gleason score of 6 , and only 6 patients had a Gleason score $>7$; it is therefore difficult to analyse this parameter.

George et al measured plasma levels of VEGF-A before and after RP in 86 patients with clinically localized PCa (12). The median reduction in VEGF from before RP to after RP was only $20 \%$. These results suggested that the changes in the post-RP VEGF values could be consistent with a noncancerous source. As was the case in our study, there was no association between plasma levels of VEGF and pre-RP PSA, Gleason score on biopsy, or clinical stage of PCa.

We found that VEGF-A expression was strongly associated with the Gleason score of PCa. This marker could therefore play a prognostic role in localized PCa. To our knowledge, our current study is the first to analyse the prognostic value of VEGF-A expression in PCa. Some previous studies analysed the prognostic value of VEGF-C expression. VEGF-C causes proliferation of lymphatic endothelial cells and plays a role in tumor lymphangiogenesis (1). Li et al compared the expression of VEGF-C receptor (VEGFR-3) in benign prostate hyperplasia and in PCa (13). These authors found that VEGFR-3 was up-regulated in PCa. Moreover, they found a correlation between VEGFR-3 expression and preoperative PSA, Gleason score and lymph node metastases. Jennbacken et al found a higher expression of VEGF-C in patients with lymph node metastases than in those with localized PCa (14). Since our current report is the first to analyse the prognostic value of VEGF-A expression in PCa, our results need to be confirmed by further studies.

In our study the clinical outcome of patients was not analysed. Over the last decade, the oncological results of RP 
have improved markedly, owing to better patient selection and enhanced technique (15). Furthermore, the interval between treatment and disease recurrence is often longer than two years. To determine whether VEGF-A has an effect on the risk of PCa recurrence and progression, a large cohort of patients with long-term follow-up is mandatory. A major prospective study that will analyse plasma levels of VEGFA, VEGF-A expression in prostatic tissue, and patient outcome is currently under way in our department.

In summary, we found that plasma levels of VEGF-A were not associated with the established prognostic factors of localized PCa. On the contrary, the expression of VEGF-A in PCa tissue was strongly associated with the Gleason score of cancer. These findings suggest that the expression of VEGF-A in prostate tissue could have a prognostic impact in localized PCa. Because only sparse data are available in the literature, further evaluation of clinical outcome is mandatory to determine the prognostic value of VEGF expression in localized PCa.

\section{References}

1. Hicklin DJ and Ellis LM: Role of the vascular endothelial growth factor pathway in tumor growth and angiogenesis. J Clin Oncol 23: 1001-1027, 2005.

2. Soulitzis N, Karyotis I, Delakas D and Spandidos DA: Expression analysis of peptide growth factors VEGF, FGF2, TGFB1, EGF and IGF1 in prostate cancer and benign prostatic hyperplasia. Int J Oncol 29: 305-314, 2006.

3. Koul D, Shen R, Garyali A, Ke LD, Liu TJ and Yung WK: MMAC/PTEN suppressor gene regulates vascular endothelial growth-factor mediated angiogenesis in prostate cancer. Int $\mathbf{J}$ Oncol 31: 469-475, 2002.

4. Duque JL, Loughlin KR, Adam RM, Kantoff PW, Zurakowski D and Freeman MR: Plasma levels of vascular endothelial growth factor are increased in patients with metastatic prostate cancer. Urology 54: 523-527, 1999.

5. Shariat SF, Anwuri VA, Lamb DJ, Shah NV, Wheeler TM and Slawin KM: Association of preoperative plasma levels of vascular endothelial growth factor and soluble vascular cell adhesion molecule-1 with lymph node status and biochemical progression after radical prostatectomy. J Clin Oncol 22: 16551663,2004
6. Walsh K, Sherwood RA, Dew TK and Mulvin D: Angiogenic peptides in prostatic disease. BJU Int 84: 1081-1083, 1999.

7. George DJ, Halabi S, Shepard TF, Vogelzang NJ, Hayes DF, Small EJ and Kantoff PW: Cancer and Leukemia Group B 9480: Prognostic significance of plasma vascular endothelial growth factor levels in patients with hormone-refractory prostate cancer treated on Cancer and Leukemia Group B 9480. Clin Cancer Res 7: 1932-1936, 2001.

8. Kanda S, Miyata Y and Kanetake H: Current status and perspective of antoangiogenic therapy for cancer: urinary cancer. Int J Oncol 11: 90-107, 2006.

9. Ma ZS, Huynh TH, Ng CP, Do PT, Nguyen TH and Huynh H: Reduction of CWR22 prostate tumor xenograft growth by combined tamoxifen-quercetin treatment is associated with inhibition of angiogenesis and celluler proliferation. Int J Oncol 24: 1297-1304, 2004.

10. Peyromaure M, Goulvestre C, Fulla Y, Grabar S, Debre B and Dinh-Xuan AT: Serum levels of vascular endothelial growth factor in patients undergoing prostate biopsies for suspicion of prostate cancer. Urology 66: 687-691, 2005.

11. Banks RE, Forbes MA, Kinsey SE, Stanley A, Ingham E, Walters $\mathrm{C}$ and Selby PJ: Release of the angiogenic cytokine vascular endothelial growth factor (VEGF) from platelets: significance for VEGF measurements and cancer biology. Br J Cancer 77: 956-964, 1998.

12. George DJ, Regan MM, Oh WK, Tay MH, Manola J, Decalo N, Duggan S, Dewolf WC, Kantoff PW and Bubley GJ: Radical prostatectomy lowers plasma vascular endothelial growth factor levels in patients with prostate cancer. Urology 63: 327-332, 2004.

13. Li R, Younes M, Wheeler TM, Scardino P, Ohori M, Frolov A and Ayala G: Expression of vascular endothelial growth factor receptor-3 (VEGFR-3) in human prostate. Prostate 58: 193-199, 2004.

14. Jennbacken K, Vallbo C, Wang W and Damber JE: Expression of vascular endothelial growth factor C (VEGF-C) and VEGF Receptor-3 in human prostate cancer is associated with regional lymph node metastasis. Prostate 65: 110-116, 2005.

15. Galper SL, Chen MH, Catalona WJ, Roehl KA, Richie JP and D'Amico AV: Evidence to support a continued stage migration and decrease in prostate cancer specific mortality. J Urol 175: 907-912, 2006. 